\title{
Afterword: Could Heracles Have Gone About Things Differently?
}

\section{Alastair Pennycook}

It is never hard to find the latest news of the progress of this many-headed and foul-breathed monster English. No longer in its aquatic cave awaiting the arrival of Heracles, it now strides across the earth, devouring school systems, reorganizing social relations and polluting minds. The newest country on the planet, the Republic of South Sudan, for example, has announced that the sole language of secondary education will be the official language - English. And from there, as is all too often the case, the gradual downward creep of English may start, so that elementary schools will have to introduce English, in order to prepare students for secondary education. The increasing pressure to provide better access to English language resources broadens the base of English education.

In Korea, which has perhaps been gripped by 'English frenzy' (yeongeo yeolpung) more than any other country (see Park, this volume), this downward pressure now means that the average age of children starting to study English in and around Seoul is 3.7 years (Bai, 2011). This average figure accounts both for the $7.3 \%$ of children between the ages of three and five that have not yet started studying English, the $6.6 \%$ who begin learning English even before they reach two years of age, as well as the $1.3 \%$ of mothers who have been opting for so-called antenatal English education. Along with such early learning, Korea is now home to 'English villages', replete with castles, post offices and native speakers (or, at least, blond Caucasians, who look, in this racialized concept, like native speakers should). And if Koreans aren't importing English, they are exporting themselves: more than 40,000 school-aged Korean children - known as jogiyuhaksaeng (early overseas students) - are studying in the US, Canada, the UK, Australia, New Zealand, Singapore, the Philippines, Malaysia and elsewhere. Typically, the young Korean children go to live overseas with their mothers and 'this particular form of separated family is referred to as a "wild geese" family, who live apart so that they can educate their children in English-speaking countries' (Jeon, 2010: 59). For some students, this works; for others, they struggle to achieve adequate academic English in school, fall behind in their knowledge of Korean and end up somewhere inbetween.

Meanwhile, in Singapore, the former Prime Minister Lee Kuan Yew has announced that he feels the American version of English will probably 
prevail over other forms, and teachers may have to eventually accept this as inevitable. So while there may be no room for 'Singlish' in the Singapore school system, there may well be more acceptance of American English (Leow, 2011).

From Arizona in the USA, there has been some relatively good news for a change: 'State education officials will no longer force schools to retrain - or reassign - English immersion teachers because they speak with an accent.' (Fischer, 2011). Until recently, state officials had been documenting instances where teachers pronounced 'the' as 'da', for example, or 'another' as 'anudder' and on this basis, obliged such teachers 'with an accent' to retrain or be reassigned. Meanwhile, in Utah, USA, 'Utah's driver license law continues to force most refugees to take the exam in English, despite efforts to make the process easier for new arrivals. The language requirement has apparently led hundreds of refugees living in Utah to illegally drive with licenses from Arizona and Colorado, where translation is allowed' (Lyon, 2011). In the UK, Prime Minister David Cameron announced that 'unemployed people who cannot speak English will be forced to learn the language or risk losing their benefits' (Porter, 2011). And in Sri Lanka, the major initiative to increase English learning as part of President Mahinda Rajapaksa's 'English as a Life Skill' project has received a boost through a new agreement with India to help develop English teaching there (Radhakrishnan, 2011). This is a snapshot of just one week in the life of the foul-breathed, many-headed Hydra of English.

Such examples link to a number of the Hydra heads described in this book. In a class I teach on 'Global Englishes', one exercise we often do is to discuss the metaphors used to describe English, including several presented in this book - the Trojan Horse, for example - as well as some others, such as English as a 'Lingua Frankensteinia' (Phillipson, 2009), English as a 'killer language' (Skutnabb-Kangas, 2003) or as 'Tyrannosaurus Rex' (Swales, 1997) or English as a guilty language (and questions as to whether languages have agency and responsibility). We are also careful to emphasize that all the terms used to describe English - English as an International Language, English as a Lingua Franca, English as a Second Language, English as a Foreign Language, and so on - are equally metaphors (less colourful, perhaps, but equally parallel terms or phrases applied to language contexts to connect to a resemblance to known worlds).

As the different chapters in this book suggest, the heads of the Hydra give us many different ways of understanding the often pernicious roles English plays in the world. We see English as the playground bully in small island schools; a destructive juggernaut among Aboriginal Australian communities, as well as in Ethiopia and other regions of Africa; it appears as the nemesis, the arch-enemy, even a 'clobbering machine' of Māori in New Zealand; we see its 'malchemical' role as a standardized language that subjugates other language possibilities in Sri Lanka; English is a stern and 
intractable governess who just never seems to leave Hong Kong, and a wellintentioned auntie who, like the governess, rather overstays her welcome, meddling in family affairs and messing up the education in the Philippines and Brunei Darussalam; English works as a Trojan Horse, smuggling in cultural and ideological enemies unseen; a Siren who summons the innocent to their deaths on the rocks of broken educational promises and dismantled communities; a border, the crossing of which is an experience fraught with anxiety, tension and inadequacy; a chameleon, described in many different ways, depending on the circumstances; a partner in crime (along with Mandarin Chinese and the Singaporean government) in subjugating language variety and a reluctant partner alongside Bahasa Malaysia in Malaysian language education policy; and an intruder (though, at times, a rather fashionable gate-crasher) into the linguistic landscape of South America.

All of this gives us many thoughtful and troubling accounts of the roles English now plays around the world. This plurality of images of English is not, thankfully, yet another attempt to describe varieties of English, but has to do with its role as a divisive language (see Ramanathan, 2005; another metaphor that might have been picked up), a language bound up with economic and political relations, a language of threat, hope, desire, resistance and destruction. By contrast with the politically bland and moribund 'world Englishes' framework, with its catalogue of exoticized variety from putative norms, its celebration of 'new Englishes' emerging alchemically as a good thing for the world, the many-headed Hydra presents us only with malchemical concerns (Parakrama, this volume). Of course, the picture here is not all negative, but, generally, this is a space of critical engagement with the problems posed by English. And the metaphor itself does not present positive images: the Hydra did not have a mixture of heads, some threatening, some empowering. There were no nice heads. Thus, this book helpfully undermines most of those rosy myths about English as a language of opportunity, a language the world has chosen, a language needed for international communication, a language whose wondrous spread we should celebrate.

Beyond this, however, we need to consider some further complexities. As we look across these different accounts of English, it is clear that English is not the only player here: there are duelling aunties and partners in crime, including Bahasa Malay(sia), Chinese, Arabic, even Bislama and other local languages. The decision by South Sudan to make English the language of secondary education, for example, was also a decision to replace the former language of education, Arabic (Suleiman, 2011). It was, therefore, in this context, a decolonial move to signal freedom from what had been seen as the imposition of the former government of Sudan. We see similar politics in the move in former French colonies to move towards English. Nevertheless, the move to adopt English is a particular one. This policy for English in this 
fragile new nation is also one of nation building. All new secondary schools will be national boarding institutions, designed, in part, to foster national unity by mixing students from different states. There is some talk of introducing that other lingua franca of the region, Kiswahili, which, as Ngũgĩ wa Thiong'o (this volume) points out, is the only African language that is an active global player. This might link South Sudan more securely with its East African neighbours (especially Kenya and Tanzania), though, of course, English does this in other ways too. English is also, in another sense, a local language (Higgins, 2009), and given that the Ministry of Education is currently reviewing 240 English book titles from Kenya, these textbooks may at least have a local content.

Of course, we might hope that education beyond the primary level could continue in the indigenous languages of the country, rather than the official language - English. All indigenous languages are acknowledged as national languages, though counting and accounting for these complex language chains is difficult (Makoni \& Mashiri, 2007). When we bring the project of nation building, schooling, literacy and language education into the context of local language ecologies, we all too often fall into the trap of also having to adopt those linguistic categorizations that emerged from the context of linguistic colonialism (Errington, 2008). We might indeed wish that the 60 or so languages of the Nilo-Saharan language family (Eastern and Central Sudanic) or the Ubangi languages of the Niger-Congo family, including those, such as Zande, spoken across the fragile and Europe-constructed borders, could play a more prominent role in education and the nation. But, as Mufwene (2010) reminds us, linguists are all too often insufficiently clear:

about how countries that are rich in ecological, cultural, and linguistic diversity but are economically poor can, with their limited financial means, satisfy both the human rights of their populations to evolve out of poverty and the alleged rights of their languages to each be used in the education system and/or other cultural domains. (2010: 914)

Another complication emerges when we observe the ways in which English means different things to different Hydra heads. Indeed, what is discussed under the label of English is not always the same thing: one Hydra head, for example, is standard English - an assumed norm that may overlook the role of Aboriginal English, of Singlish; another Hydra head may be precisely these descriptions of English that do not account adequately for the political economy of English (Tupas, 2006); a different Hydra head may be the introduction of English into primary education, to the probable detriment of first-language education for many of the students; and a different Hydra head may be the role English plays in relation to neoliberal corporatization of economies and institutions. I have myself, on occasion, used the story of the blind monks and the elephant to illustrate the problem with 
understanding this many-faceted role of English. Just as each encountered a different part of the elephant and assumed the rest was made in this image (a foot leading to an image of a pillar-like being, a trunk to a flexible serpentine animal, a tail to a thin and rapid-moving creature), so we might argue that the many faces of English, or the many partial encounters with English, lead to many different images of English. For a primary student in Korea, a secondary student in South Sudan, an immigrant driver in Utah, a teacher in Arizona, an unemployed immigrant in the UK, an English teacher in Sri Lanka, English means something very different.

Ultimately, however, the elephant story is unsatisfying here. Although I have found it useful to speak of the elephantine myth of English, this story presents us with the problem that we, in fact, know what English is (an elephant), but that others fail to grasp this reality. Ultimately, this is both politically and epistemologically suspect. An image of English as hard to grasp, but ultimately elephantine, may be appealing, but fails to attend to the diversity of what English is. English is not the elephant in the room. The collective monks are, in a sense, right: English is all these things and more.

The Hydra myth gives us a different way of thinking about this, since it is not only many-headed, but also a piece of mythology. Mythologies may serve as useful metaphors, but, as Barthes (1972) reminds us, they are also complex. When we consider the myth of English (Pennycook, 2007), we need to consider not only those many myths about English that this book usefully addresses - that English automatically confers educational and economic benefit, that English is needed for international communication, that English is a language better suited to a globalized world than any other - but also that English itself is also a myth. It is the relentless repetition of the stories about this thing called English that perpetuate this mythological creature.

When we talk of English today, we mean many things and not many of them have to do with some core notion of language. The presence of English shifts not just the language ecologies of different contexts, but, more importantly, the discursive ecologies; English is not just a language, but a discursive field: English is neoliberalism, English is globalization, English is human capital. The question then becomes not whether some monolithic thing called English is imperialistic or an escape from poverty, nor how many varieties there may be of this thing called English, but rather, what kind of mobilizations underlie acts of English use or learning? Something called English is mobilized by English language industries with particular language effects. But something called English is also part of complex language chains, mobilized as part of multiple acts of identity; it is caught in a constant process of semiotic reconstruction.

So what can we do about it? We might argue that the Hydra only exists as part of a legend in which it is overcome by Heracles. The story, ultimately, is about the strength and bravery of Heracles. So is the notion of English as Hydra, we might ask, useful in the main, in order to turn those that oppose 
it into crusading heroes? The Heraclean/ Herculean (Phillipsonian? $)^{1}$ task of cutting off its heads, cauterizing the wounds before they grow back and, finally, decapitating the immortal head of English with a golden sword is, indeed, one of the great labours of this world. But might Heracles have gone about this differently? Is decapitation the best way forward? The point that we need to try to get at is this: it is not English - if by that, we mean a certain grammar and lexicon - that is the problem. It is the discourses of English that are the problem, it is the way that an idea of English is caught up in all that we do so badly in the name of education, all the exacerbations of inequality that go under the label of globalization, all the linguistic calumnies that denigrate other ways of speaking, all the shamefully racist institutional interactions that occur in schools, hospitals, law courts, police stations, social security offices and unemployment centres.

We can, by all means, as Ngũgĩ wa Thiong'o and Muhammad Haji Salleh (this book) both do and advocate, give more support to other languages, writing our poems, plays and prose in languages other than English, while also reminding ourselves that those other languages are never innocent players either in the politics of unequal semiotic resources. We need to improve our understanding of strategies of language revival and recognition and continue our battles for bilingual education (and, yes, the idea of teaching in English for the first four hours of school in the Northern Territory of Australia is disgraceful and should be discarded - see Robyn Ober and Jeanie Bell, this volume). We need to increase our battles against pernicious ideas about the benefits of standard English, to point to the negative alchemy (malchemy) of standardized English and to seize the possibilities in the radical differences of unstandardized, resistant language to help others to stand up to the playground bully, to find ways to block the wheels of the juggernaut, to tell the aunts and governesses that have overstayed their welcome that it really is time to go home.

But we also need to confront the problem of the myth, of the language ideologies that continue to construct the terms of the debate. We need to understand not only that monolingual mindsets deny the value of first language and bilingual education, but also that the idea that monolingualism is possible is part of the picture. That is to say, it is not only that so-called monolingual mindsets diminish educational and linguistic diversity, but also that the discourses that allow for the possibility of monolingualism as a concept are also complicit with this problem. The monological and enumerative strategies that link languages to worldviews, that construct languages as entities to be counted, battled over or beheaded does not ultimately help us in the struggle for a more equitable semiotic world. As Moore et al. (2010: 2) explain, this approach to languages 'privileges a conception of "languages" as neatly-bounded, abstract, autonomous grammatical systems (each of which corresponds to a neatly-bounded "worldview")'. Such an account, they argue, distracts attention from the 
complexities of speech communities and the dynamics of language contact. As Mufwene explains:

the ideal world in which (rich) linguistic diversity can be sustained is far from being ours. There are really no language rights. Many people who are struggling to improve their living conditions in the current everchanging socioeconomic ecologies are not concerned with maintaining languages and heritages, which are more properly archived in libraries and museums. The archiving is (to be) done by experts or some nonprofessional "glossophiles" (if I may suggest the term). (2010: 927)

So could Heracles have done things differently? Not if he is stuck only in his own mythological struggle with the many-headed Hydra - the Hydra and Heracles are mutually constitutive. But if he were given a chance to step outside this myth, to rethink the terms of the battle, to reconsider what we mean by the Hydra or by language, things might start to look a bit different. We need to move away from the reification and exoticization of languages, suggesting that to maintain one's L1 is somehow a guarantor of self-esteem, a consistent worldview, a useful education and economic advancement. As Mufwene (2010) makes very clear, all of this depends on the particular language under discussion, the nature of local ecologies and economic opportunities, the value accorded to different languages, the movement of people in search of livelihoods and so on:

Linguistics must address issues arising from the real world of socioeconomic inequality more globally and not just from the point of view of languages as maps of world views and illustrations of mental/cognitive variation. The rest of the world happens to see languages as tools at the service of mankind, and this perspective is an equally legitimate one, just as is the view that a language can be an asset or a liability to a person or a population. (2010: 927)

The focus needs to move away from 'languages' and to focus instead on language practices (Pennycook, 2010), on the intersections between discursive practices (orders of meaning), generic practices (iterative forms) and stylistic practices (making new possibilities), in relation to economics, employment, migration and education. We need careful research that explores this and which separates the romantic glorification of language diversity from the harder questions about knowledge, existence and expression.

\section{Note}

(1) Robert Phillipson and I are really not so very far apart in much of what we argue and advocate. Indeed, far more people are content to align us with each other, than to separate our positions. Little asides such as this should not be taken too seriously. 


\section{References}

Bai, J. (2011) Children start learning English by age 4. The Korea Herald, August 30, 2011.

Barthes, R. (1972) Mythologies (Annette Lavers, trans.). New York, NY: Hill and Wang (original work published 1957).

Errington, J. (2008) Linguistics in a Colonial World: A Story of Language, Meaning and Power. Oxford: Blackwell.

Fischer H. (2011) State halts practice of forcing action on 'accented' teachers. Arizona Daily Star, 31 August, 2011. Online at: http://92starnet.com/news/local/education/ precollegiate/article c8aa52c2-e844-5f2a-8264-4ad180a003ea.html.

Higgins, C. (2009) English as a Local Language: Post-colonial Identities and Multilingual Practices. Bristol: Multilingual Matters.

Jeon, J. (2010) Issues for English tests and assessments: A view from Korea. In Y. I. Moon and B. Spolsky (eds) Language Assessment in Asia: Local, Regional or Global? (pp. 55-82). Seoul: Asia TEFL.

Leow, S.W. (2011) American English 'likely to prevail': Lee Kuan Yew. Straits Times, Sept 7, 2011. Online at http://www.straitstimes.com/BreakingNews/Singapore/Story/ STIStory 710302.html

Lyon, J. (2011) English-only thwarts Utah refugees seeking driver licenses. The Salt Lake Tribune, Sept 7, 2011. Online at http://www.sltrib.com/sltrib/home2/52501715-183/ english-refugee-test utah.html.csp

Makoni, S. and Meshiri, P. (2007) Critical historiography: Does language planning in Africa need a construct of language as part of its theoretical apparatus? In S. Makoni and A. Pennycook (eds) Disinventing and Reconstituting Languages (pp. 62-89). Clevedon: Multilingual Matters.

Moore, R., Pietikäinen, S. and Blommaert, J. (2010) Counting the losses: Numbers as the language of language endangerment. Sociolinguistic Studies 4 (1), 1-26.

Mufwene, S. (2010) The role of mother-tongue schooling in eradicating poverty: A response to Language and poverty. Language 86 (4), 910-932.

Pennycook, A. (2007) The myth of English as an international language. In S. Makoni and A. Pennycook (eds) Disinventing and Reconstituting Languages (pp. 90-115). Clevedon: Multilingual Matters.

Pennycook, A. (2010) Language as a Local Practice. London: Routledge.

Phillipson, R. (2009) Linguistic Imperialism Continued. London: Routledge

Porter, A. (2011) Learn English to get a job or lose benefits, says Cameron. The Telegraph, 15 September 2011. Online at http://www.telegraph.co.uk/news/politics/davidcameron/8761311/Learn-English-to-get-a-job-or-lose-benefits-says-Cameron.html

Radhakrishnan, R. K. (2011) Sri Lanka, India join hands to teach English in schools. The Hindu, September 13, 2011. Online at http://www.thehindu.com/news/international/ article2450642.ece

Ramanathan, V. (2005) The English-Vernacular Divide: Postcolonial Language Politics and Practice. Clevedon: Multilingual Matters.

Skutnabb-Kangas, T. (2003) Linguistic diversity and biodiversity. The threat from killer languages. In C. Mair (ed.) The Politics of English as a World Language: New Horizons in Postcolonial Cultural Studies (pp. 31-52). Amsterdam: Rodopi.

Suleiman, G.S. (2011) South Sudan: Arabic to Be Phased Out From Secondary Schools in Three Years. Website, accessed 23 August 2011. http://allafrica.com/stories/ 201108231678.html

Swales, J. (1997) English as Tyrannosaurus Rex. World Englishes 16 (3), 373-82.

Tupas, R. (2006) Standard Englishes, pedagogical paradigms and conditions of (im)possibility. In R. Rubdy and M. Saraceni (eds) English in the World: Global Rules, Global Roles (pp. 169-185). London: Continuum. 